Article

\title{
A Gene for Maintaining Sustainable Cultural Specificity of Contemporary Architecture-National Deep-Rooted Nature
}

\author{
Linlin Shan
}

College of Fine Arts and Design, Tianjin Normal University, Tianjin 300387, China; shanlinlin@tjnu.edu.cn

\begin{abstract}
Due to the differences in locality, ethnicity, environment and culture, architecture has an obvious and sustainable cultural specificity. Even in the era when modernism swept the world, this specificity still exists, and its sustainability stems from the gene of architectural cultural specificitythe national deep-rooted nature. This paper puts forward the concept of the national deep-rooted nature of architecture with the cultural specificity of contemporary architecture as the starting point. Then, the connotation of cultural specificity and national deep-rooted nature of architecture is explained in detail, and the relationship between contemporary architectural creative thinking and national deep-rooted nature is widely explored and discussed in depth. A theoretical research framework of contemporary architectural creation is constructed in which the national deep-rooted nature is regarded as the main line, and the architectural form, space, aesthetic creation consciousness are regarded as the basis.
\end{abstract}

Keywords: contemporary architecture; sustainability; national deep-rooted nature; cultural specificity

\section{Introduction}

Cultural specificity is an academic issue in many research fields. Since the expansion of contemporary architecture worldwide, modern architecture has been transferred from regional "national character" to globalized "universalization" [1,2]. Currently, with the leadership of frontier technology and economic demands, architecture with high technology, ecological architecture, virtual architecture and other creation consciousnesses and concepts have been widely integrated into the design of architecture and the cultural attribute of architecture has been melted and weakened by science and technology and rational thinking [3-5]. Furthermore, in terms of the cultural attributes of contemporary architecture, we always highlight whether the architecture has cultural specificity, or whether the architecture has national character or ethnicity [6,7]. However, the basis for solving the problems is to clarify the problems as follows: why does architecture have cultural and national attributions, what factors affect them, and why is contemporary architecture inseparable from these attributes. To solve the above problems, we are required to discuss the intermediate gene to maintain the architectural cultural specificity-the national deep-rooted nature of the indigenous peoples in the location of the architecture, which makes contemporary architecture and architecture in any future era continue to have cultural specificity.

In this paper, the cultural specificity of architecture refers to the differences of various architectural cultures in regional climate characteristics, ecological environments, and characteristics of designers, such as their thinking ways, values, religious beliefs, and the angle of observing things [8]. The national deep-rooted nature of architecture refers to the original motivation and stable thinking ways of a national group for long-term creation, and the architectural style and features gradually formed in practice. The national deeprooted nature refers to the special material in the national core, which is considered that it is not reflected through people's subjective consciousness, but some physical material from the original ecology at the beginning of national formation is retained in the blood

Copyright: () 2022 by the authors Licensee MDPI, Basel, Switzerland. This article is an open access article distributed under the terms and conditions of the Creative Commons Attribution (CC BY) license (https:// creativecommons.org/licenses/by/ $4.0 /)$. 
of each member of the nation. It presents the natural environment, ethnic origin, way of thinking, and values of each individual, making it continuously different from other ethnic groups to form cultural specificity. To clearly show the sustainable culturally specific gene of contemporary architecture - the national deep-rooted nature, and provide a novel research idea for improving contemporary architectural culture theory, this paper uses the formal logic deduction method to understand the relationship between cultural specificity and the national deep-rooted nature of architecture, and how they affect each other.

The main contributions of this paper are as follows:

(1) Put forward the concept of the national deep-rooted nature of contemporary architecture, and analyze the relationship with architectural cultural specificity.

(2) Use the formal logic deduction method to analyze the point of view of this paper, put forward the concept of national deep-rooted nature, with typical cases as material, through specific analysis, anatomy, judgment, and then association with the cultural specificity of architecture to obtain the reasoning point.

(3) Find out the specific manifestations of contemporary architectural culture caused by national deep-rooted nature, determine their performance factors such as national emotion, culture cognition and national rationality, and judge the correlation with variables in architectural form, space, and aesthetics.

\section{Literature Review}

\subsection{Cultural Specificity}

Research on cultural specificity is mainly from the perspective of sociology, which covers many disciplines. What is the significance for the concept of cultural specificity? People's intuitive impression is the universal symbol of the different ethnic groups, such as language, way of thinking, social culture, behavior and habits, etc. [9]. However, when we are required to definitely and normatively point out its concept, we are able to find out many standpoints.

In the 18th century, the philosophers and writers of France and Germany discussed the problems of cultural specificity. For example, Immanuel Kant talked about the elegance of the French and the impetuous nature of British [10]. Montesquieu wrote in his famous book on The Spirit of Laws: "The climate, history, religion, customs and other external factors are regarded as forming elements of the national general spirits while the heritage element is not considered." Montesquieu thinks that people are the same in essence [11]. The interpretation of cultural specificity by cultural anthropology highlights the achievements of theoretical construction. The idea of "cultural mode" put forward by American anthropologists Ruth Benedict has a strong sense of logic. She thinks that "For culture, we should suppose a huge arc of potential human purposes and motivations ... ; as a kind of culture, its unification depends on a certain segment of the huge arc. Every human society in every region has made relevant selection in its own customs and culture. [12]" The historical evolution of culture is a process of melting and conflicting. In the process of national development, some substances are selected, absorbed, gradually institutionalized, rationalized and standardized; furthermore, they are also strengthened as the behavioral and psychological characteristics, while other substances are suppressed, discarded, and excluded so that they have lost overall value and meaning. An ideal style, a kind of behavior and mental model are gradually formed in the process of integration and cohesion [13]. Finally, the so-called cultural specificity is formed.

In recent years, some scholars have understood cultural specificity from the relationship between social needs and culture. For example, scholars who study from the perspective of originality and cultural specificity of contemporary visual art believe that "The visual industries are not created for pleasure and entertainment as much as they are created to reflect the human knowledge of the universe and life ... they are a kind of meta knowledge and we see them enter in the society of knowledge in all their manifestations and results on a manner that can be an expression for cultures with their varied and multifaceted characteristics" [14]. Scholars who study the expression of ethnic and cultural 
differences in language believe that, "language is a way to express the differences of traditions and beliefs in different countries" [15]. Scholars who study the cultural differences of emotion and tactile sensation believe that "Further understanding of cultural contexts has led to the pursuit of understanding personality on levels beyond concepts of inherent behavior ... personality is the result of more culturally specific characteristic adaptations influenced by society, culture, motives, drives, and coping mechanisms" [16].

Some Chinese scholars think that the cultural specificity shows the subject consciousness of humanistic spirits, the difference between the psychological characteristics, behavioral patterns, traditional customs, ways of thinking, cultural orientation, and other aspects. Different cultural models shape and affect people's beliefs, behavioral patterns and ways of discussing the world and their own experiences. Moreover, the difference will also display its own feature of persistent continuation, some kind of particularity of variation caused by cultural conflicts and melting with the development and evolvement of nations and countries. Finally, it is also referred to as "national culture" [17-19].

To sum up the above key points, we are able to say that the cultural specificity is manifested as the life customs, behavior and way of thinking, psychological quality and emotional experience defined and restricted within a scope which is formed by a nation in the long living experience and practice and manifested by a particular behavioral pattern. In the contemporary context, it is regarded as the integration form of social members. It can also be seen that ethnic and regional culture are the important embodiment of ethnic spirit. The above research is the summary of expression forms of cultural specificity made by national scholars and social scholars, and also involves the reasons for its formation. However, in the field of architectural creation, it is superficial and rigid because they are not able to understand and explain the creation process of the architecture. Therefore, we combine the thinking ways of architectural creation to obtain the genes that maintain the cultural specificity of architecture, and put forward the concept that architecture has national deep-rooted nature.

\subsection{Cultural Specificity of Architecture}

What is the cultural specificity of architecture? Scholars all over world all have a perfect explanation and elaboration for cultural specificity of architecture. In the Western society of the 18th century, the German philosopher Hagel has deeply discussed this issue. He thinks that art is marked with national spirit while the real art of architecture is the external existing style of the spirit [20]. French historian Taine has highlighted the restricting role of three factors of race, environment and age in "Philosophy of Art" on art. Furthermore, he also thinks that nation is the "internal power" for the development of art [21].

Studies on the cultural specificity of contemporary architecture are mostly carried out by looking at the diversity and differences of architectural culture, such as explaining this phenomenon from the perspective of architectural culture comparison. Korean scholars made a comparative study of architectural conceptions between the East and the West [22], and Shao J. studies Chinese ancient geomantic theory (Feng Shui theory) and Greek and Roman urbanism [23].

Since the 1920s, the issue of cultural specificity of architecture has been gradually highlighted in China. There were extensive and in-depth discussions on it in Chinese architecture field. For example, Zhang Qinnan, Hou Youbin, and Chen Zhihua have respectively elaborated the cultural connotation of architecture from the aspects of Chinese characters, national character and local culture. Their points of view are: "The cultural specificity of architecture of China refers to the classical and conventional architecture which has represented the orthodox of the nation. Its biggest charm is the memory of the traditional art of architecture" [24]; "In the development history of a nation, the characteristics of common region, language, common culture, social and economic life have been gradually formed. In terms of the form of architecture, a variety of cultural characteristics are distinct from that of other groups. Moreover, in the architecture, the custom and system, religious belief, 
cultural and psychological behavior norms and ideal pursuit of the specific national groups are manifested [25]". Some contemporary Chinese scholars focused this issue from the relationship between traditional culture and architectural culture, such as the three major ideological systems that affect the traditional Chinese architectural culture: the functional thoughts, ritual thoughts and philosophical thoughts of the unity of heaven, earth and man [26]. Some scholars reflected that the contemporary city's styles are similar, hoped to integrate regional traditional culture into architectural design, and put forward some suggestions on the development of regional architecture using cultural specificity [27].

If the above points of views are summed up, it is thought that the cultural specificity of architecture is actually the styles and feature of architecture formed in the long-term creation and practice for specific groups in specific area. It is based on the national character of culture, that is to say the tradition of architecture. It is also defined as the value orientation used to maintain and develop the national architectural culture. Moreover, it is the sum of the national collective thinking and consciousness manifested by architectural form, space and other tangible objects. It has strong cultural sustainability. When confronting the pressure of a dominating foreign culture, we are able to maximize the integration of the foreign culture through the selection of destinations so as to endow the architecture with new forms in the core of national culture and realize the revival of cultural specificity.

The above studies generally discuss the cultural specificity of architecture. No scholars have explained why architecture has cultural or national attributes, and it is the key to architectural cultural attributes. Only by understanding the key genes to maintain the cultural specificity of contemporary architecture, can we judge the future road of architectural design and creation.

\section{Research Method}

Compared with previous studies, the innovation of this study lies in the use of the formal logic deduction method to explain the concepts of architecture. The basic law of formal logic deduction is the law of thinking, not the law of cultural research. Cultural specificity itself does not exist to follow the same thinking process. The role of the formal logic deduction method is to ensure the certainty of thinking. Only when thinking has certainty can it correctly reflect the world and exchange ideas. Any correct theory conforms to the logic law, and the correctness of the theory can also be deduced using the logic law. Formal logic is a method to study thinking, and it is a deduction process of putting forward concepts, judging and reasoning views, which is in line with the research thinking pattern of this paper. (Figure 1) This study first puts forward the concept of national deep-rooted nature of contemporary architecture, and through literature review and analysis of cultural specificity of architecture, the key factor to maintain the specificity of architecture culture-cultural nationality is extracted. Then, based on the variables of architectural form elements, the ethnic root characteristics of architectural culture are put forward and further the national deep-rooted nature of contemporary architecture is proposed and analyzed. Combined with creative design factors such as form, space and aesthetics of contemporary architecture and national deep-rooted expression such as national emotion, cultural cognition and aesthetic ideal, it is deduced that the unique cultural specificity of contemporary architectural creation is the accumulation of national psychological unconsciousness and a dynamic process of conscious and unconscious.

In addition, this paper also uses the typical case study method, takes the typical architectural cases as the examples, analyzes and decomposes the specific problems in the architectural culture, and then carries out the connection with the national deep-rooted nature to obtain the research purpose. In this paper, the works of some representative architects in China, Japan, and Europe are used as analysis cases. The cases in China and Japan are obtained by field trips, and the European cases are obtained through Internet inquiry. The methods of induction, classification and comparison, and analysis of typical works are adopted, so as to have a comprehensive understanding of contemporary architectural culture. Through the collation of architectural examples, we have chosen architectural 
works from 1960 to 1980 with 36 in Europe, 48 in Japan, and 15 in China. There are 63 in Europe, 112 in Japan, and 120 in China from 1981 to 2000. There are 108 works in Europe, 201 in Japan and 215 in China from 2001 to 2020. The main cases in this paper focus on those from 2001 to 2020 and these are the latest architectural works, which reflect the specificity of architectural culture and have more cutting-edge value of research.

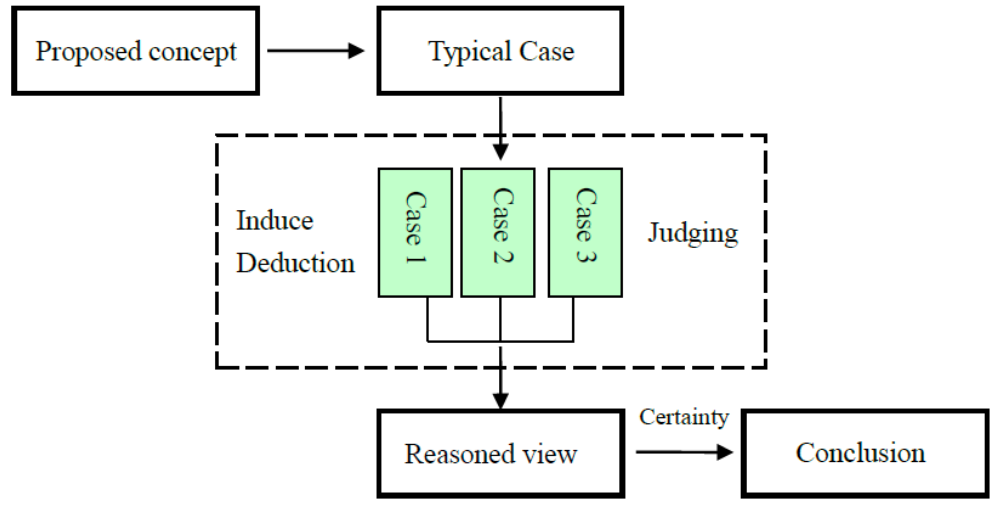

Figure 1. The schematic diagram of the deduction method of this paper.

\section{The Theoretical Construction of National Deep-Rooted Nature of Contemporary Architecture}

If we try to figure out why contemporary architecture is endowed with cultural specificity, we are required to start from the resource of national culture. The factor for its generation is the deep-rooted nature with nation as the orientation. Therefore, what is the national deep-rooted nature? If the cultural specificity is the conscious and subjective manifestation of humanistic spirits, the national deep-rooted nature is the instinct gene for human race and the manifestation of the unconscious behavior of the subject and "tacit knowledge" [28,29]. National culture is just the superficial product of the gene, which is the standard to distinguish different nations, while the national deep-rooted nature is the gene of the standard.

National deep-rooted nature was researched in an early period in Japanese academic fields. In Japanese, it is called "the origin of a nation" [30]. The corresponding concept of the national deep-rooted nature is ethnicity, race, national character, national spirit and so on, in the Western academic languages. They are mainly researched and elaborated on from the perspective of the ontology of philosophy. For example, the American scholar Robin Cohen and other scholars of theory of national origin think that the national character is endowed by nature and it is existing in language, the field, the common national psychology, the recognizable national identity, and other objective entities [31]. The Swiss psychologist Carl Jung thinks that race is the nature which is accumulated by our ancestors and emerged in our memory base, affecting us from time to time whether we admit it or not [32]. The British scholar Stephen Fenton thinks that national character is actually the social construction for the social members with the same culture and blood, as well as the logic connotation of classification system constructed around them.

The national deep-rooted nature has appeared in the Chinese traditional philosophy in the early time. It is defined as the one with the nature and essence of ethnical group. The so-called root means growing by root. Sun Xingyan has cited and interpreted the words of Ma Rong of the Han Dynasty: "It is hard for plant to root as the root is the basis for food which is called hundreds of grains" [33]. In modern academic circles, the deep-rooted nature is actual a neutral word. It does not come from rational deliberation but it is an instinctive and unconscious behavior manifested in the substance in the blood of each member [34]. Therefore, cultural specificity is formed in different nations which have the specific different psychological characteristics, way of thinking, traditional customs, cultural orientation, ways of behavior and the pursuit of the ideal. 
If architectural culture is the manifestation of the subject consciousness of humanistic spirits of the builder, the national deep-rooted nature is actually the instinctive gene of subject consciousness. National character is the superficial product of the gene and it is endowed with the display feature of architectural forms. However, what is reflected by the national deep-rooted nature of architecture is the original diving force created by an ethnic group and stable principle of thinking. Therefore, the national deep-rooted nature of contemporary architecture refers to the special substance in national core. It is not manifested by the subjective consciousness but it is a physical substance in the blood of each member which is the original ecology in the early formation of the nation. It displays the natural environment of each individual, blood of the ethnic group, population, language and so on so as to make them continuously distinguished from that of other nations.

The concept "national deep-rooted nature of architecture" put forward from the perspective of national deep-rooted nature and creative thought of architecture is the so-called original tradition of architecture which affects the form, space, aesthetics, and so on of the architecture so that the architecture is able to return to its original cultural state unconsciously when confronting with the invasion of foreign dominating culture. It is also endowed with an instinctive and unconscious behavior. Due to its attachment, cognition, and sense of belonging to its own ethnic group and the common culture, the deep-rooted nature of architecture has a strong grass-root nature which is unparalleled strong and rigid. To see it from the development history of human culture, the reason for the manifestation of a national character is that when the foreign and powerful civilization is making the national culture of its own slump into a crisis, it will make an instinctive reaction to stimulation while it is not a deliberation based on rational thinking. Therefore, it is endowed with the ideological tendency of the subject's unconscious. What must be explained is that the national deep-rooted nature architecture will never exclude the national parts of the foreign architectural culture completely, but it must be in line with the original culture of the nation.

The deep-rooted nature of architecture belongs to the sustainable collective or group unconsciousness, the experience within the nation, as well as the tacit knowledge. It is no longer coming from the individual impulse of the architect and his desire, but from the dissemination of architecture creation consciousness made by the traditions and habits of the creators in a long time accumulation. It will make the architect form a stable and sustainable psychological state in practicing process of architecture creation which has been gradually formed as "foresight" and "potential" to distinguish the ways of creative thinking, value concept and ideal pursuit of other nations. Therefore, it also restricts the practice and value orientation of architectural creation of the nation it belongs to.

To some extent, the architectural consciousness, which is self-generated and selfsurpassing, is actually the essence for one kind of architecture to survive. The stimulation of creativity and the promotion of creation realm for architects first come from the cognition and respect of their own national spirits. When the architects are not able to surpass the limitations of architectural creation and realize their value, they must be melted into a general national culture or spirit for self-confirmation so as to obtain a sense of belongings of emotion and spiritual support.

Generally speaking, the national deep-rooted nature of architecture is not seen very frequently in the works of modern architectural theory or papers as a concept. There are two common forms: one is the discussion of global consciousness and root-seeking consciousness when researching the variety of modern architecture. The second one is the discussion of ideology formed when researching the nationalization of architecture.

\section{The Features of National Deep-Rooted Nature of Architectural Culture}

\subsection{The National Deep-Rooted Nature Is Universal}

There are obvious features for the national deep-rooted nature of architectural culture which have made us definitely know of its existence. First, the national deep-rooted nature of contemporary architecture has pervasive characteristics which are manifested in two 
aspects. On the one hand, as a sustainable gene, the national deep-rooted nature is the core for the generation of the architectural creative thinking of the nation. Furthermore, it is manifested in the specific forms and aesthetics of architecture and the creative thinking and ideas are recognized by the masses, so it is the origin of national cognition and sense of belonging. On the other hand, it refers to the cultural specificity possessed by any an architecture which is different from other architectures because of the difference between its own natural environment and historical encounters and experience. This cultural specificity is endowed by nature and it is also connected to the root of the creators. Moreover, it will never change because the creator is born in a foreign land or the architecture is completed in a foreign land. For example, the Japanese Miho Museum designed and created by the Chinese architect Ieoh Ming Pei is filled with tranquility, nature, and special attributes of the unique Chinese style [35]; the China National Grand Theatre designed by French architect Paul Andreu uses an island to imply and express the romance of French people [36,37]; the Langen Foundation Museum of Art designed by the Japanese architecture Tadao Ando uses the empty space experience to show the Japanese national character and Shinto worship [38]. Although in these architectures, the local culture has been taken into careful consideration, the mastering and sublimation of essence of the "community" where the designers have been living are also unconsciously embodied (Table 1).

Table 1. The architectural works created by architects in other ethnic regions.

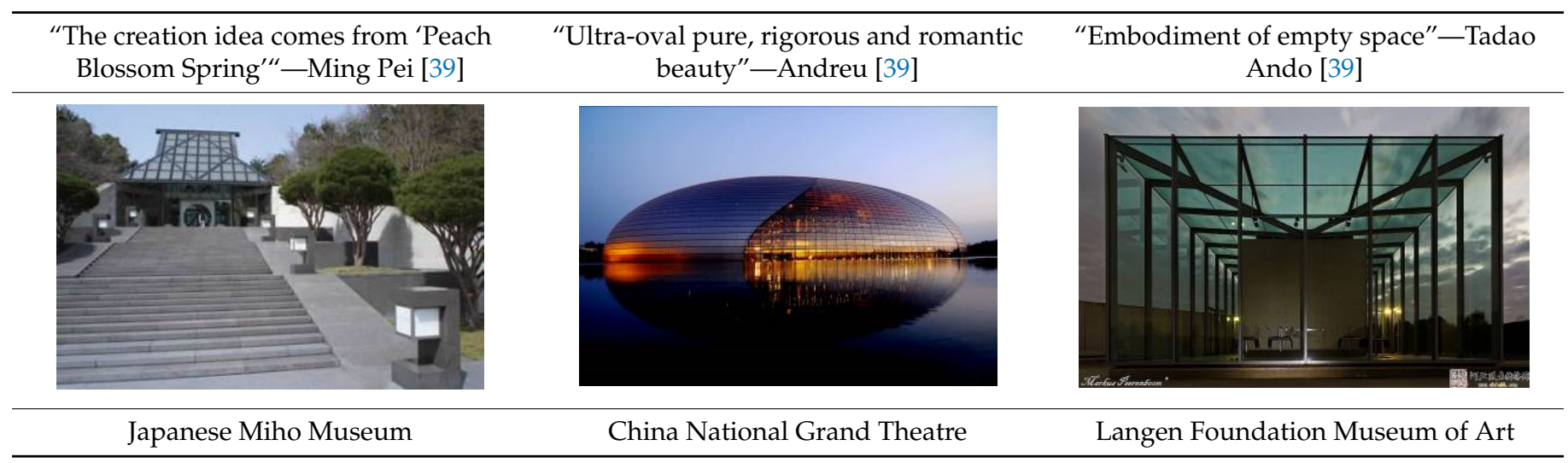

\subsection{The National Deep-Rooted Nature Is Unique}

The national deep-rooted nature of the cotemporary architecture also has its particularity which is mainly referred to as the features of national deep-rooted nature of different architectures. It is non-substitutable and unique. Furthermore, it cannot be shifted casually, eliminated and copied in an easy way. Each nation in the world has generated its own cultural gene because of the difference of natural environment, blood, language, population, and so on. Therefore, it is endowed with the unique features, unique advantages, and unique flaws as well as its unique values.

Based on such genes of the national deep-rooted nature, the architecture created by it is also irreplaceable and it is particularly obvious in traditional architecture. Modern architecture is regarded as the product of industrial civilization. Many people do not recognize its cultural specificity, not even to mention the deep-rooted nature. However, we are able to review the difference between the German architecture and American architecture in the preliminary period of the generation of contemporary architecture. Taking the master of modern architecture as the case, the works of Mies van der Rohe show us an open skeleton and neat appearance, flexible space and simple but exquisite details. The driving force of his architecture comes from the principle of a sense of balance with German classical style and the modern style of extreme minimalism, expressing the rigorous and rational creation of the German people [40]. The grassland residential house and organic building concept are used by Frank Lloyd Wright, a master of modern architecture in the United States, to create the harmony of the base and nature, manifesting the nature 
of the material and the space of the dramatic and embodying American characteristics such as democracy and freedom, practicality, and rationality [41]. Although they all belong to modern architects, there is still an obvious difference between them.

\subsection{The National Deep-Rooted Nature Is Stable and Sustainable}

The deep-rooted nature of contemporary architecture is also endowed with the characteristics of stability and sustainability. In the development process of architecture, the stability and sustainability of national deep-rooted nature is always being penetrated in it. It will be shifted, faded or eliminated easily with the migration of the creator, the transformation of social forms, the shift of the time, and the change of geography. However, it is not also unchangeable. It will change with the baptism of the age and "sedimentation" of generations; however, the change is often not obvious. It is like a tree with deep root system and prosperous leaves. Although it has undergone vicissitudes of life, its root of life still exists.

The reason the national deep-rooted nature of architecture is endowed with stability and sustainability is that the formation of the objective world of subjective consciousness of architecture, nature, blood, language, population, and so on requires thousand years of sedimentation. To explain it from a structural point of view, the driving force and principle of architecture are the deep layer and axis layer for architectural design; what is more, they are also the internal factors of architectural culture, which determines the formation, variation, and heritage of architecture. Compared with the middle layer of architectural culture - the surface layer of national and architectural culture-architectural form and style, it is more stable and sustainable. If the shift of the architectural form and style does not touch the driving force and principle of creation, the form and style will be continuously inherited. Therefore, as the driving force of architectural creation and the gene that generate ways of thinking, the deep-rooted nature has become the core of architectural culture and ultimate reference with its stable and robust constitutive property.

The stability and sustainability of the national deep-rooted nature is often manifested as subtle inheritance and continuity of architectural tradition internally while it is also manifested as the relatively independence in the intertwining of architectural forms externally. As the pre-existing thing of the subject consciousness, its unconscious forms have been penetrated by the form, space, and aesthetics of architecture.

\section{The Manifestation of National Deep-Rooted Nature of Contemporary Architectural Culture}

The national deep-rooted nature is the instinctive gene of a nation. It is like the roots of a tree, invisible underground, but all the nutrition for the leaves is coming from them. Likewise, it must be expressed in a phenomenon which is national emotion, cultural cognition, national ideal and so on. The phenomenon will directly be applied in architecture and manifested as form, space, and aesthetics.

\subsection{The Manifestation of National Emotion in Architectural Forms}

The most direct and external manifestation of the national deep-rooted nature is national emotion. In the surviving and development process of a nation, the national emotion and national mood are the instinctive genes with subjective and unconscious behavior [42]. In the architectural activities of human beings, the most preliminary and external form of manifestation directly reflected the emotion with the character of the nation in the original form. In the process of the surviving and development process of a nation, the members will generate pleasure, anger, sorrow and joy, hate and disgusting, happiness and depression and other national emotions and moods. At the same time, the feeling of them consists of a national emotion [43]. It is the emotional cognition and "the feeling of the tacitness" formed by a nation on the basis of common region, economic life, social life, and historical development. It is also closely related to religion and culture. In the process of the generation and development of culture, the elements of the culture will 
be transformed into the psychological and emotional structure of individual, such as poetry, drawing, architecture, and other specific forms. It not only constitutes the continuation and development of forms, but also constitutes the emotional experience of the citizens [44]. The common ground of the emotional experience makes them much easier to communicate. As an unconscious behavior and atmosphere, it is often refined in a specific group. The common group of emotional experience is the most sensitive nerve of the citizens. The emotion of a nation will directly reflect or refract their "national deep-rooted nature".

Just as everything has two aspects, so does national emotion which not only has a positive initiative, but also a negative effect. In the architectural activities of human beings, national emotion, the external deep-rooted nature has a direct instructing significance for the preliminary and external form of architecture.

The word form in architecture is understood as the temperament and quality manifested by the architecture. Shape is the gesture and style which exists in real life; while the pattern is the expression and modality of architecture which are reflected by the human brain. It includes basic elements of body, surface, line, point, as well as the shape, color, quality and quantity. There are three categories of understanding for the form of architecture: "one refers to the external form; two is the dynamics and posture; the third one is the analytical research under the exertion of subjective initiative and multiple factors" [45]. The process of affection of architecture forms and national emotion is also the process perceived by the individual of the nation. People are able to perceive the stimulation brought by the multiple elements of architecture forms by observing and appreciating the architecture and carrying out activities in the architecture. When the information is received, it will be integrated and sorted out in the human brain so that people are able to be enlightened in terms of architectural form by envision, comparison and contrast with the visual perception being formed and moods being generated. Finally, it will form a certain form and emotional mode. If the process is completed and become the creation principle for instructing the architectural forms, it must meet the spiritual tendency of the human ethnical groups which originates from the national deep-rooted nature.

The architectural form should not only meet the spiritual demands of people, but also be consistent with the appearance of the architecture which is pervasively agreed to by the citizens of that nation [46]. Otherwise, it will be recognized by the masses, while different people with different cultures have different feelings to the same object, so architectural form has a national deep-rooted nature and it is also one of the forms which can reflect a national deep-rooted nature.

For example, in modern Japan, the architectural form has always been consistent with geometry structure of architectural elements, the slender form from the traditional architecture to contemporary architecture, at the same time, it also manifests the relatively complicated psychology of the forms and so on, because the cautious, natural deep-rooted nature of the Japanese nation has formed a certain cultural form $[47,48]$. It is easy to see from Table 2 that the traditional Miaozhao temple in Niigata and the contemporary Kyoto courtyard of Litiao's famous painting have very obvious geometric architectural forms. The traditional Kyoto residential house and the contemporary national new art center in Tokyo show the slender conceptual form in the internal composition of architecture. In addition, the architectural environment of Kyoto's Nijo Castle and the contemporary N-House show the importance of the overall natural form of architecture. The deep-rooted emotional experience of the Japanese nation has made them "despise the substance cognition, be strong in comprehensive thinking and be weak in independent analysis" when they create by confronting architectural form; they also highlight vague and intuitive experience, despite demonstration of logic and other thinking tendencies. Their architectural works have the characteristics of imagery, intuition, ambiguity, integrity, and introversion [49]. 
Table 2. The sketch of Japanese architecture.

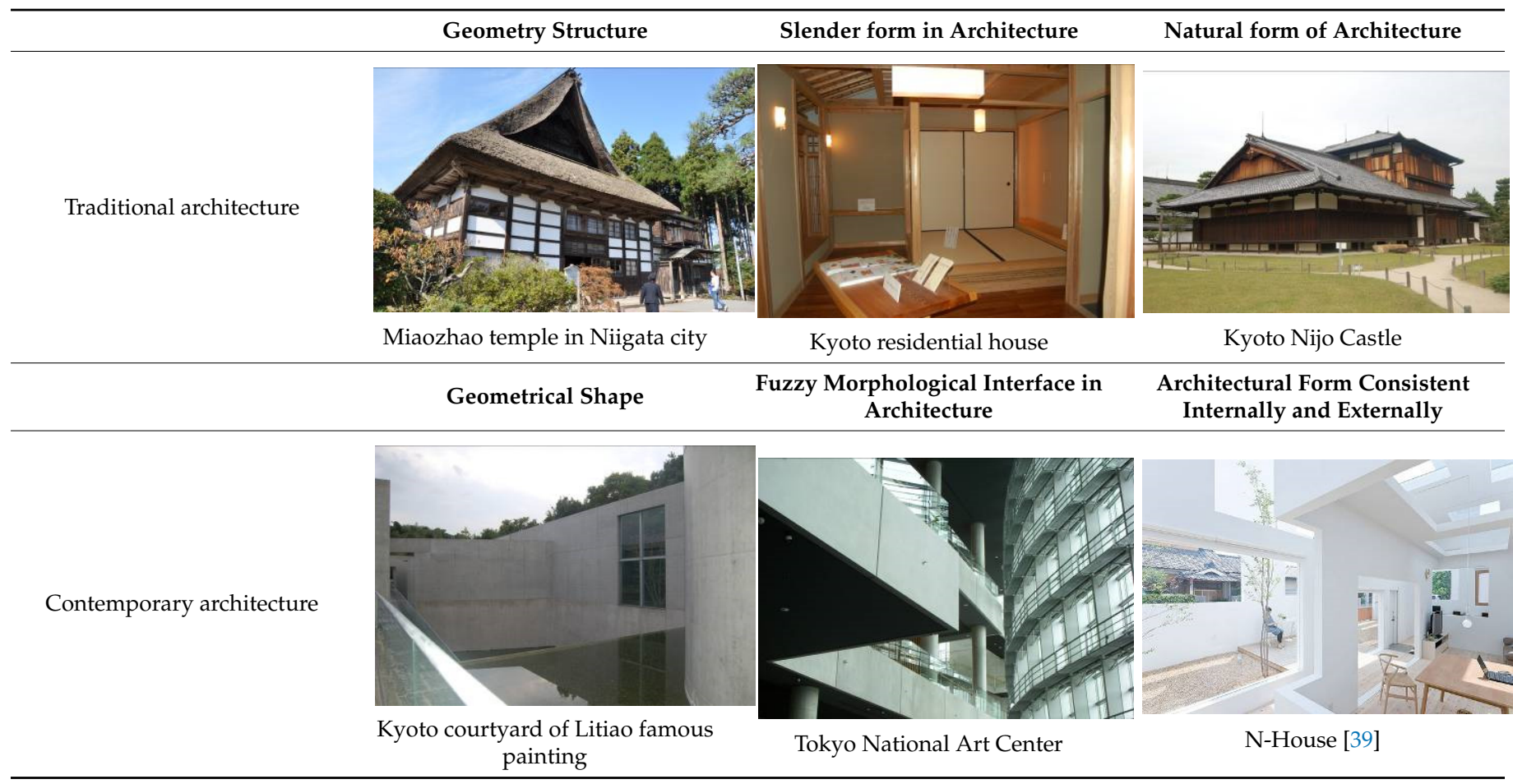

\subsection{The Presentation of Cultural Cognition in Architectural Space}

Cultural cognition is the overall opinion of the whole nation on the nature of the world, the connections between different things, the relationship between people and the world, the status and role of people in the world, and so on. To some extent, the nation dominated by a kind of cognition will deal with problems according to the opinion formed by such a cognition with the cultural specificity being formed as a result of this process. The cultural specificity is reflected in the forms of consciousness and materialization in all aspects of social groups and it will also feedback to society [50].

The architectural activities of human beings are adaptations between subjective consciousnesses and the objective world multiple times over. The cultural characteristics of the human groups who create the architecture are the important condition for the architecture to obtain laws of movement and the cultural cognition of a national group is one of the characteristics [51]. Moreover, cognition is in the central position of the system and the architectural activities can effectively complete the construction and development only if they are able to adapt, integrate, and melt into this kind of cognition. Therefore, the cultural cognition of national groups of human beings manifests the subjective activities by architecture form and endows the architecture with spiritual connotation. At the same time, cultural cognition is a process of psychological organization in which objects are perceived actively and the cognition is made selectively. It depends on the emotional property manifested or conveyed by specific aesthetic objects with integrity, initiation, emotion, and perception. The relationship between cultural cognition and creative thinking in architecture is shown in Figure 2. 


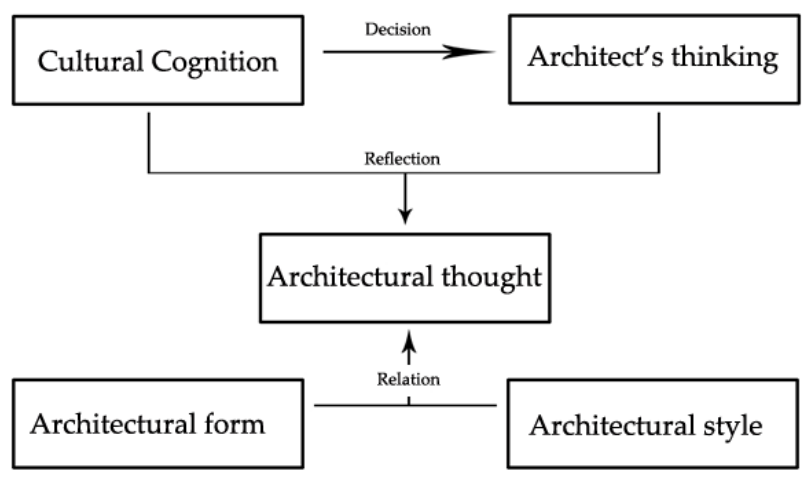

Figure 2. Relationship between cultural cognition and creative thinking of architecture.

In the long-term development process of architecture, different nations have their own specific perceptions for architectural creation based on their living environment, historical tradition, cultural background, and other factors; in particular, they have a variety of ways of exploring the spatial forms of architecture so that the spatial interests and characteristics with cultural characteristics used are the symbolized characteristics used to distinguish the different architectural forms.

For example: the cultural cognition of Chinese people is endowed with a kind of the doctrine of the mean, which comes from a geographical environment that was enclosed for several thousands of years and a social environment in which Confucianism is respected and imperial autocracy dominates, so cultural cognition has the characteristics of enclosure, obedience, gentleness, and generosity, which are all the external manifestation of doctrine of the mean [52]. This has an important effect on the cognition of Chinese people. Cognition is further manifested as the special and timing cognition which advocates for harmony between humans and nature, the integration of time and space and the interaction between beings and nothingness, environment cognition which is formed naturally with five positions and four deities. The cognitions are transformed into a cognition concept in which the stuff and self-ego are integrated in the process of architectural creation, expressing the deep-rooted nature of the Chinese culture $[53,54]$. This concept in which the stuff and self-ego are integrated is mainly manifested by spatial creation of architecture.

The cultural cognition of Chinese people, which advocates harmony between humans and nature, the integration of time and space, and the interaction between beings and nothingness is manifested as the internal and organic integration between space and subject, space and human beings; furthermore, it is intangible and it is the integrity of continuous movement in the result of integration between the "nothingness" which is indefinite and "beings" which are the objects with a certain form, being elaborated by the Theory of Yin and Yang [55]. From the perspective of the theory of Western contemporary architecture, it is believed that the architectural space is the materialized existence form opposite to the time and it is manifested as the square with length, width, and height [56,57]. Their opinions are deep and speculative, highlighting pure reasoning, experience and practice, which is quite different from those in Chinese world [58-60]. (Figure 3) The results are triggered by the different cultural cognition which is rooted in the national deep-rooted nature. The national deep-rooted nature makes them have different cognitions to space which are manifested by creational space in architecture.

Chinese architects generally think that architectural space is generated by "nature", which means that "it is generated in the granted way" according to the particular environment $[45,61]$. This is the inherent cultural cognition of Chinese people. Something highlighted in the content is the human perceptional action for environment and the subjective behavior endowed by the environment. Traditionally, Chinese people are eager to imagine the architectural spatial environment as a kind of context (such as the practice of meditation) in which a certain behavior will occur (the practice of meditation for life). This behavior comes from the context and vice versa. The higher the artistic conception is, the vaster and deeper the special the behavior of human beings will be [62]. Therefore, 
our architecture respects natural space from beginning to the end. There is no definite dividing line between the traditional architectural space and the natural environment which are required to interact with one another with the continuity of outdoor space being countertraded so as to make the internal and external space be endowed with a vague and unexpected feeling of space. For example, the Hall of Distant Fragrance, the Humble Administrator's Garden in China highlights the continuity of the internal and external space, and the coordination between space and nature [63]. However, when we are studying modern architecture, we are still accustomed to using the courtyard space, which is integrated with space and adopting the traditional unreal, fuzzy space method to complete the special feeling between human and architecture. In this way, the viewers are unable to have a comprehensive understanding of the architecture so that their imagination is exerted fully [64]. For example, Confucius Research Institute in Qufu designed by Mr. Wu Liangyong integrated the traditional space of courtyard with the modern neat and clean space [65]. In modern Chinese architecture, a sense of far-reaching feeling, a place of mobility and a continuous space which cannot be cut off are generally pursued. Furthermore, it is explored positively in the process. For example, the Suzhou Museum designed by Ming Pei reflects everywhere the theme that "generation" is "nature", which is the main principle of contemporary architectural space in China, swaying between the ambiguous and slender architecturem and nature [66] (Table 3).
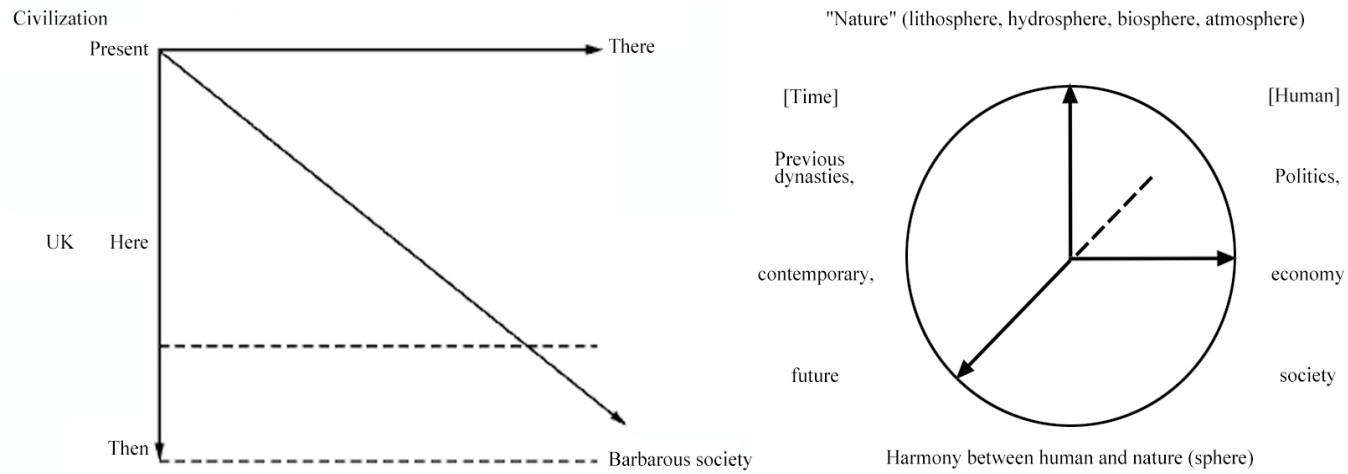

Figure 3. The "separation of nature and human" in the western world and "the integration between nature and human" in Chinese world.

\subsection{The Performance of National Ideal in Architectural Aesthetics}

The national ideal is the highest pursuit of the value of a nation and it is also a pure form of the national "innate nature". It is the common purpose of national emotion and cultural cognition; it is the control and upgrading of practical activities within the deep heart of the nation and the thinking style beyond general science and logic. It can penetrate into the true nature of the nation and it contains the rational cognition of the inexorable law and development trend of the objective world. It is the sustainable achievement which is consistent with the law and in line with the purpose of creative imagination activities. It belongs to the highest level of the form of consciousness and its basic features are the unity of the subject and object, the future graphic character, innovation and transcendence, the possibility of realization, etc. [67]. Every nation has its own highest ideal and all their ideology is dominated by it. 
Table 3. Chinese architectural space highlights on the heritage of natural elements.

\begin{tabular}{|c|c|c|c|c|}
\hline Development Phase & Cultural Cognition & Opinion of Architecture & $\begin{array}{l}\text { Representative } \\
\text { Architecture }\end{array}$ & $\begin{array}{c}\text { Diagrammatic Presentation } \\
\text { of Cases }\end{array}$ \\
\hline Ancient time & & $\begin{array}{l}\text { It highlights the continuity } \\
\text { of the internal and } \\
\text { external space, as well as } \\
\text { the unexpected feeling of } \\
\text { space. }\end{array}$ & $\begin{array}{c}\text { The natural space of the } \\
\text { Hall of Distant Fragrance, } \\
\text { the Humble } \\
\text { Administrator's Garden } \\
\text { highlights coordination } \\
\text { between space and nature } \\
\text { [63]. }\end{array}$ & 14t \\
\hline Modern time & $\begin{array}{l}\text { Natural cognition: } \\
\text { harmony between human } \\
\text { and nature, the integration } \\
\text { of time and space and, and } \\
\text { the integration between } \\
\text { beings and nothingness }\end{array}$ & $\begin{array}{l}\text { Based on the modern } \\
\text { architecture, the } \\
\text { traditional architectural } \\
\text { elements are integrated. }\end{array}$ & $\begin{array}{c}\text { Confucius Research } \\
\text { Institute in Qufu designed } \\
\text { by Mr. Wu Liangyong has } \\
\text { integrated the traditional } \\
\text { space of courtyard with } \\
\text { the modern neat and clean } \\
\text { space [65]. }\end{array}$ & \\
\hline Contemporary & & $\begin{array}{l}\text { The concept that } \\
\text { "generation" is "nature" is } \\
\text { the main principle of } \\
\text { contemporary } \\
\text { architectural space in } \\
\text { China }\end{array}$ & $\begin{array}{l}\text { Suzhou Museum designed } \\
\text { by Ming Pei is like thin } \\
\text { rain swaying between the } \\
\text { ambiguous and slender } \\
\text { architecture and nature } \\
\text { [66]. }\end{array}$ & \\
\hline
\end{tabular}

How is architectural aesthetic generated? This is a question of the general evolution of architectural creative thinking under the influence of external factors. That is to say, the development standard of architectural aesthetics depends on external factors that act on the subject. The external factors come from nature, society and ethnic groups. The historical development of these typical characteristics, which belongs to a certain range, has become an independent and conscious aesthetic activity; therefore, it is also heightened to the aesthetic of the consciousness dimension of the main body of architectural creation [68].

The aesthetic appreciation of architecture is the visible expression of the consciousness of the cultural specificity, rising to the level of creative thinking, extracted and sorted on purpose. It is also the perceptual manifestation the rational relationship of the unity of opposites for the objective and subjective bodies. The aesthetic standard of architecture is consistent with the cultural specificity of the nation [69]. In the externalized process, where this ideal relationship depends on the materialized form, not only has the original root of the ethnic characteristics been further strengthened but it is also endowed with a new way of expression because it has a particular perceptual form as a transformation medium. This new form of expression has become the scale of the pros and cons of ethnic groups after the accumulation and precipitation. In architecture, it is related to the aesthetic consciousness expressed by the external form. It is also the spiritual sustenance for the architecture to become the art and its most deep layer is actually the national deep-rooted nature.

For example, the unique aesthetic expression of the Japanese nation uses the form of sensibility to imitate everything in the universe and its laws so as to create a natural beauty with universal appeal. The understanding of beauty in Japan can be summarized as "sorrow to things", "vanity and silence" and "mysterious profundity" [41,70]. The beauty of nature constitutes the main body and the base of the Japanese aesthetic consciousness [71]. With beautiful natural scenery, Japan has engaged with the beauty of nature from the dawn of the nation and has a deep love for nature and the special affection. The Japanese cognition of architectural beauty is natural and the natural beauty has become the prototype of aesthetic culture of Japanese architecture [72]. 
In the post-modern period in the West, the word ecology is widely accepted by people as a brand-new thinking pattern for architectural creation. It highlights the relationship between human and architecture, nature and architecture, as well as the regeneration of the building itself. Furthermore, the ecological structure and recycling use are regarded as the standards for measuring the merits and defects of the various types of constructions. It is in full compliance with the evaluation criteria of the architectural system from the Japanese architectural tradition to the contemporary one. In such a background, the transformation of ecological aesthetics of architecture has become the most basic principle for the organic combination of ecology and nature pursued by Ando Tadao, Kengo Kuma, Fujimori Terunobu, and other architects [73-76]. Furthermore, in the process of exploration of architectural creation, the transformation of aesthetic consciousness from "pure natural architecture" to "natural ecological architecture" is manifested. For example, Kengo Kuma focuses on the relationships between architecture and human, architecture and nature, and the ecological creative thinking of architectural functions, and his representative works include Hiroshige Museum and Yusuhara Civic Centre [74]; Kisho Kurokawa advocates the idea of symbiosis between man and nature, and symbiosis between architecture and nature. His representative works include Nakagin Capsule Tower and Tokyo National Art Center [77,78]; Hasegawa Itsuko advocates the space concept of "tolerance" and "symbiosis" in architecture, and her representative works include Hunan Culture Center and Zhuzhou Multiple Project Center [79] (Table 4).

Table 4. Natural and ecological architecture of Japanese architects.

\begin{tabular}{|c|c|c|c|}
\hline Architect & $\begin{array}{c}\text { Creative Thinking of } \\
\text { Architecture }\end{array}$ & Natural Architecture & Ecological Architecture \\
\hline Kengo Kuma & $\begin{array}{l}\text { He focuses on the relationship } \\
\text { between architecture and } \\
\text { humans, and architecture and } \\
\text { nature. Lets the architecture } \\
\text { disappear into nature. It is } \\
\text { transformed from integration } \\
\text { in the form to ecology of } \\
\text { architectural functions [74]. }\end{array}$ & Hiroshige Museum [39] & Yusuhara Civic Centre [39] \\
\hline Kisho Kurokawa & $\begin{array}{l}\text { He thinks that architecture } \\
\text { shifted from mechanization to } \\
\text { life; symbiosis between } \\
\text { human and nature, symbiosis } \\
\text { between architecture and } \\
\text { nature are possible }[77,78] .\end{array}$ & Nakagin Capsule Tower & Tokyo National Art Center \\
\hline Hasegawa Itsuko & $\begin{array}{l}\text { She advocates the space } \\
\text { concept of "tolerance" and } \\
\text { "symbiosis" of architecture so } \\
\text { as to embody the harmonious } \\
\text { relationship between } \\
\text { architecture and humans, } \\
\text { architecture and society, and } \\
\text { the harmonious relationship } \\
\text { between architecture and } \\
\text { nature [79]. }\end{array}$ & Hunan Culture Center [39 & $\begin{array}{l}\text { Zhuzhou Multiple Project } \\
\text { Center [39] }\end{array}$ \\
\hline
\end{tabular}




\section{Conclusions}

Just as the famous architect Marcus Vitruvius Pollio of the Rome times said: "Architecture is a reflection of human nature" [80,81]. The reason architecture can considered art rather than an object is that people are different, while there is also tradition deeply rooted in the nation which exists prior to the birth of any individual. That is the so-called "national deep-rooted nature".

The writing process of this paper is also the process for the author to perceive the creative thoughts and ideas for the development of contemporary architecture. It is found that most of the research on the cultural specificity of contemporary architecture is limited to the cultural specificity being promoted or not or its manifestation form in architecture after some literature are collected, sorted, and researched. There is less research on the topic as to why contemporary architecture is endowed with cultural specificity. Therefore, this paper takes the causes of the cultural specificity of contemporary architecture as the research objectives, and using the formal logic deduction method, demonstrates it in combination with theories of architecture and sociology. Then the concept that architecture has national deep-rooted nature is put forward. It also discusses the combination of national emotion, cultural cognition, and national ideals with the expression of contemporary architectural form, space, and aesthetics. Based on detailed research on the cultural specificity and national deep-rooted nature of architecture, it is summarized that in the contemporary architectural circle, the phenomenon of cultural specificity is a direct result influenced by the national deep-rooted nature; furthermore, it also digs deeply into the national core supporting this form, as well as the national emotions, cultural cognition and national ideals manifested by the contemporary architectural form, space, and aesthetics. Finally, it is deduced that the cultural specificity of contemporary architecture is the accumulation of the national mentality, a kind of shift between consciousness and non-consciousness, as well as the dynamic process gradually formed, and it is the result of the primitive national deep-rooted nature. On this basis, this paper draws the following innovative conclusions. (1) Taking the cultural specificity of contemporary architecture as the breakthrough point, this paper puts forward the theoretical connotation of the national deep-rooted nature of contemporary architecture. (2) From the national emotion, cultural cognition and aesthetic ideal to find out the expression form of national deep-rooted nature to affect cultural specificity of contemporary architecture, determine its influencing factors, and judge the correlation with variables in architectural form, culture, and aesthetics. Then we further put forward the possible expected research in the future: (1) In this paper, contemporary architectural creation theory is based on the cultural specificity of architecture as the breakthrough point and contemporary architectural creation as the research objective. This paper argues that the national deep-rooted nature of architecture is universal, it is not only reflected in contemporary architectural creation, and architecture in other periods should also have a national deep-rooted nature. Therefore, further research on it has the potential to improve the theoretical system of national deep-rooted nature of architecture. (2) The concept and connotation of the national deep-rooted nature of contemporary architecture needs to be further explored and developed in the future. The national deep-rooted nature of architecture is a philosophical problem related to ideology. As an architectural theory, it should have a standard terminology. At this stage, it can only be temporarily defined as "national deep-rooted nature" in ethnology, and it is necessary and urgent to further clarify, standardize, and develop this theory in the future.

Funding: This research was financially supported by the Tianjin General Plan of Art and Science Project (No. E20016).

Institutional Review Board Statement: Not applicable.

Informed Consent Statement: Not applicable.

Data Availability Statement: Not applicable. 
Acknowledgments: The authors acknowledge the support provided by the College of Fine Arts and Design of Tianjin Normal University. The authors thank the anonymous reviewers for their comments, which contributed to an improvement of this paper.

Conflicts of Interest: The authors declare no conflict of interest.

\section{References}

1. Deng, M. An Interpretation of the Essence of Modern Architecture's Rational Space. J. Northeast. Univ. 2014, 16, 568.

2. Colquhoun, A. Modern Architecture; Oxford University Press: Oxford, UK, 2002.

3. Xue, E.L. High-Tech Architecture with Concerns on Environment. Cultural tradition and Ecological Balance. World Archit. 2000, 4, 26-29.

4. Li, X.J.; Chen, X. Sustainable Ecological Architecture Design. Archit. J. 2001, 5, 47-50.

5. Dong, Y. Study on the Technicality and Artistry of Virtual Cultural Heritage of Architecture. Master's Thesis, Donghua University, Shanghai, China, 2006.

6. Lu, J.S. Contemporary Value of Architectural Regionalism Studies. Archit. J. 2008, 7, 15-19.

7. Martin, K.; Naylor, L. Diversity Orientations: Culture, Ethnicity and Race. In Cultural diversity in the United States; Bergin \& Garvey: Westport, CT, USA, 1997.

8. Sun, Y. A Research into the Motivation of Experiential Philosophy and Cultural Idiosyncrasies in the Domain of English-Chinese Emotion Metaphors. Foreign Lang. Educ. 2010, 31, 45-48.

9. Chen, C.; Liu, D.P. The Interpretation on Specificity of Symbol Language System of Chinese Traditional Architectural Landscape Cultural Region. J. Lanzhou Univ. Technol. 2011, 37, 118-123.

10. Rohlf, M.; Immanuel, K. The Stanford Encyclopedia of Philosophy; Edward, N.Z., Ed.; Stanford University: Stanford, CA, USA. Available online: https:/ / plato.stanford.edu/entries / kant/?rid=903123293s840c38 (accessed on 12 October 2021).

11. Aayla, K. Nationalism: The World's Attention, Accept and Classification Problem; Publishing House of Constant Taggart: Jyvaskyla, Finland, 1964; pp. 64-68.

12. Ruth, B. Culture Pattern; Social Science Literature Press: Beijing, China, 2009; pp. 78-79.

13. Ruth, B. Patterns of Culture; Routledge: London, UK, 2019.

14. AI-Obaydy, H.A.H. Cultural Specificity in the Visual Industries between Originality and the Contemporariness. A Study in Anthropology of Arts. J. Univ. Anbar Humanit. 2021, 3, 24-42.

15. Marinova, K. National-Cultural Specificity of Somatic Phraseological Units in Bulgarian and Japanese (From the Point of View of Their Productivity). Studia Philol. 2018, 37, 195-208.

16. Thompson, J.; Camp, J.R.; Trimble, J.E. Universality vs. Cultural Specificity of Personality. Wiley Encycl. Personal. Individ. Differ. 2020, 4, 281-286. [CrossRef]

17. Jiao, J.Z. The Perspective Theory Research on Chinese Modern National Character and Its Values; China Social Sciences Press: Beijing, China, 2009; p. 16.

18. Tan, W.F. Try to Discuss the Cultural Characteristics of Architecture. Sci. Technol. Inf. 2011, 2, 70.

19. Sun, Y.; Wang, Y. The Dual Structure of Embodied-Cultural Effects on Metaphorical Cognition. J. Shenzhen Univ. 2021, 38, 136-143.

20. Hegel, G.W.F. Elements of the Philosophy of Right; Cambridge University Press: London, UK, 1991.

21. Taine, H. The Philosophy of Art; Holt \& Williams: New York, NY, USA, 1873.

22. Lee, J. Comparative Study of Architectural Conceptions between the East and the West. Archit. Res. 2021, 23, 49-54. [CrossRef]

23. Shao, J. Archaic Chinese Geomancy and Greco-Roman Urbanist Thought: Towards a Cross-cultural History of Urban Design. Master's Thesis, University of Saskatchewan, Saskatoon, SK, Canada, 2021.

24. Zhang, X.W. Issues on Chinese Architectural Thoughts in the New Period. Ph.D. Thesis, Tianjin University, Tianjin, China, 2012.

25. Zhao, H.X. Reconsideration to the Ethnic Building under Globalization View. J. Minzu Univ. China 2011, 6, 110-112.

26. Su, X.Y. Modern Inheritance Strategies of Chinese Traditional Architectural Culture Thought. Front. Soc. Sci. Technol. 2019, 1, 62-73. [CrossRef]

27. Guifen, L.; Yu-Che, H.; Bei, S. A study for Application Research of "Regional” Architectural Culture in Architectural Design Courses. In Conference Series: Earth and Environmental Science; IOP: Bristol, UK, 2019; Volume 330, p. 022012. [CrossRef]

28. Yingkun, C.; Rui, S. The Awakening of a Cultural Subjective Consciousness: William Theodore de Bary's Introduction of a "Chinese Tradition of Liberalism to the World". Sinol. Res. Newsl. 2020, 39, 1-8.

29. Shin-Hwa, L. The Features of Russian National Psychology According to the Theories of Archetypes. Foreign Lang. Stud. 2012, 17, 113-135.

30. Dalian, U.F.L. New Japanese-Chinese Dictionary; Liaoning People's Publishing House: Shenyang, China, 2017 ; p. 5.

31. Cohen, R. Global Diasporas: An introduction; Routledge: London, UK, 2008. [CrossRef]

32. Jung, C.G. The Psychological Foundations of Belief in Spirits; Princeton University Press: Princeton, NJ, USA, 2014; pp. 300-318. [CrossRef]

33. Zhonghua, P.H. Zhonghua Dictionary; Zhonghua Publishing House: Beijing, China, 2020.

34. Gao, N. Literary Discourse and National Roots in the Context of Globalization. Soc. Sci. J. 2005, 2, 139-145.

35. Suner, B. Ieoh Ming Pei; Ediciones AKAL Arquitectura: Madrid, Spain, 1999. 
36. Andreu, P. The Creation of the Beijing Opera House. J. L'ecole Paris Manag. 2008, 5, 36-42. [CrossRef]

37. Liu, L.A.; Yang, A.Q. Essay on the Collision of Chinese and French Architecture Culture at the New Millennium. J. Beijing Univ. Civ. Eng. Archit. 2013, 12, 5-11.

38. Qin, L. Tadao Ando-As Relaxed as the Breeze. Shanghai Artist. 2002, 5, 106-107.

39. Available online: http://www.google.com.hk/imghp?hl=zh-CN\&tab=wi/ (accessed on 12 October 2021).

40. Cohen, J.L. Ludwig Mies van der Rohe: Third and Updated Edition; Birkhäuser: Basel, Switzerland, 2018.

41. Pfeiffer, B.B.; Gossel, P.; Wright, F.L. Frank Lloyd Wright, 1867-1959: Building for Democracy; Taschen: Köln, Germany, 2004.

42. He, C.N. National Consciousness, National Emotion and National Spirit. Chin. Market. 2006, 26, 14-15.

43. Lin, C.D. Dictionary of Psychology; Shanghai Education Press: Shanghai, China, 2003.

44. Lei, H. Social Ideal and Spiritual Pursuit_Empirical Research on National Spirit; People's Publishing House: Beijing, China, $2009 ;$ p. 11.

45. Qi, K. Building, Space, and Form—Research on the Architectural Morphology. J. Southeast Univ. 2000, 30, 1-9.

46. Wang, J.P. Endemic Environment and Architectural Style-Analysis of Endemic Architectural Style in the West of Shanxi. The Archit. 2003, 1, 60-70.

47. Seligmann, A. Japanese Modern Architecture 1920-2015: Developments and Dialogues; The Crowood Press: London, UK, 2016.

48. Arata, I. Japanese Natural Things in the Architecture; Shinchosha Press: Tokyo, Japan, 2010.

49. Wang, J.H.; Yang, Z.S. Japanese Thinking Way and Confucianism. Jpn. Stud. 1994, 6, 141-152.

50. Tomasello, M.; Carpenter, M.; Call, J.; Behne, T.; Moll, H. Understanding and Sharing Intentions: The Origins of Cultural Cognition. Behav. Brain Sci. 2005, 28, 675-691. [CrossRef]

51. Zhang, H.Y. Nativism Culture Perception on the Elements of City Imagoes. Urban Probl. 2004, 5, 6-11.

52. Pang, P. The Doctrine of the Mean and Three Parts. Lit. Hist. Philos. 2020, 4, 21-27.

53. Yang, B.Z. Considerations on the Cognition and Inheritance of Chinese Traditional Culture in Gardening Art. Chin. Landsc. Archit. 2009, 11, 77-80.

54. Hou, Y.B. Chinese Architectural Aesthetics; Heilongjiang Science and Technology Press: Harbin, China, $1997 ;$ p. 9.

55. Gu, G.H. Chinese Traditional Culture. J. Yangzhou Univ. 1999, 6, 34-40.

56. Dewey, J. 7. Pragmatic America. In America's Public Philosopher; Columbia University Press: Columbia, SC, USA, $2021 ;$ pp. 49-54. [CrossRef]

57. Kenny, A. A New History of Western Philosophy; Oxford University Press: Oxford, UK, 2010.

58. Peng, F. "Harmony between Human and Nature" of Confucianism Concept: The Source to Construct the Theory of Sustainable Development. China Popul. Resour. Environ. 2001, 11, 141.

59. Zhang, J.X.; Rao, T. Temporal Narration of Culture-Analysis of Colonial Culture Discourse. J. Guangzhou Univ. $2012,11,27$.

60. Zuo, B. Ring and Linearity: Comparison of Chinese and Western Cultural Characteristics. J. Soc. Sci. 2001, 12, 68-72.

61. Zhou, X.B. Philosophy Ideas in Chinese and Western Traditional Architecture. J. Tianjin Univ. 2009, 11, $172-175$.

62. Liu, Y.; Hu, S.J. Zen Space. New Archit. 2008, 1, 46-47.

63. Wu, Z.J. Humble Administrator's Garden. Lit. Hist. Mon. 2014, 2, 50.

64. Zhang, Z.Y. Chaotic Space-The Starting Point of Chinese Architectural Philosophy in the 21st Century. Archit. J. 2002, 1, 60-68.

65. Wu, L.Y.; Zhu, Y.F. Environmental Design Based on Confucian Aesthetic-A Case Study of the External Environmental Planning and Design of the Confucius Institute in Qufu. Chin. Landsc. Archit. 1999, 15, 10-14.

66. Chen, W. New Suzhou Museum. World Archit. 2004, 1, 12-15.

67. Lei, H.; Yang, S.Z.; Liu, X.J.; Ouyang, K. Empirical Study on Social Ideal and Spirit Pursuit of National Spirit; People's Publishing House: Beijing, China, 2009.

68. Wang, J. Aesthetic Anthropology; People's Publishing House: Beijing, China, 2021; p. 8.

69. Yan, G.Z. Aesthetic Interpretation of Architecture. J. Peking Univ. 1991, 5, 54-61.

70. Ellis, C. Direct Radical Intuition: Toward an 'Architecture of Presence' through Japanese ZEN Aesthetics. Master's Thesis, University of Cincinnati, Cincinnati, OH, USA, 2011.

71. Imamichi, T. Oriental Aesthetics; Sanlian Publishing House: Beijing, China, 1991; p. 133. [CrossRef]

72. Tian, Y.S. Japanese Aesthetics through the Tea Ceremony-Centered on “He Jing Qing Ji”. Abil. Wisdom 2010, 1, 160-161.

73. Frampton, K.; Andō, T.; Wrede, S. Tadao Ando; Museum of Modern Art: New York, NY, USA, 1991.

74. Bognar, B.; Kuma, K. Kengo Kuma: Selected Works; Princeton Architectural Press: Princeton, NJ, USA, 2005.

75. Kim, H. Illusion of Ruin and Rebirth-A Study on Terunobu Fujimori's Diploma Design (1971). J. Archit. Inst. Korea Plan. Des. 2012, 28, 203-210. [CrossRef]

76. Miyamoto, K. The Only Japanese Architecture; Gakugei Press: Tokyo, Japan, 2011.

77. Kurokawa, K. Das Kurokawa-Manifest; Jovis Berlin: Berlin, Germany, 2005.

78. Funo, S. Dreams of Japanese Young Architects; Zhangguo Press: Tokyo, Japan, 2011.

79. Huang, H.F.; Hu, M.X. Inclusive, Symbiotic and Harmonious Architecture-Analysis of the Architectural Philosophy of Hasegawa Itsoko. Constr. Archit. 2007, 9, 76-78.

80. Leon, B.A. Alberti Architectural Theory: Ten Books on Architecture; China Architecture and Building Press: Beijing, China, 2010; p. 151.

81. Chen, P. The Formation of Order System-The Architectural Theories from Leon Baptista Alberti to Andrea Palladio. Lit. Art Stud. 2015, 8, 137-148. 